\title{
EFFECT OF DELAYED EMERGENCE ON CORN GRAIN YIELDS
}

\author{
By \\ KYLE DON LAWLES \\ Bachelor of Science in Plant and Soil Sciences \\ Oklahoma State University \\ Stillwater, Oklahoma \\ 2006
}

Submitted to the faculty of the

Graduate College of the

Oklahoma State University

in partial fulfillment of

the requirements for

the Degree of

MASTERS OF SCENCE

December 2006 


\section{EFFECT OF DELAYED EMERGENCE ON CORN GRAIN YIELDS}

Thesis approved:

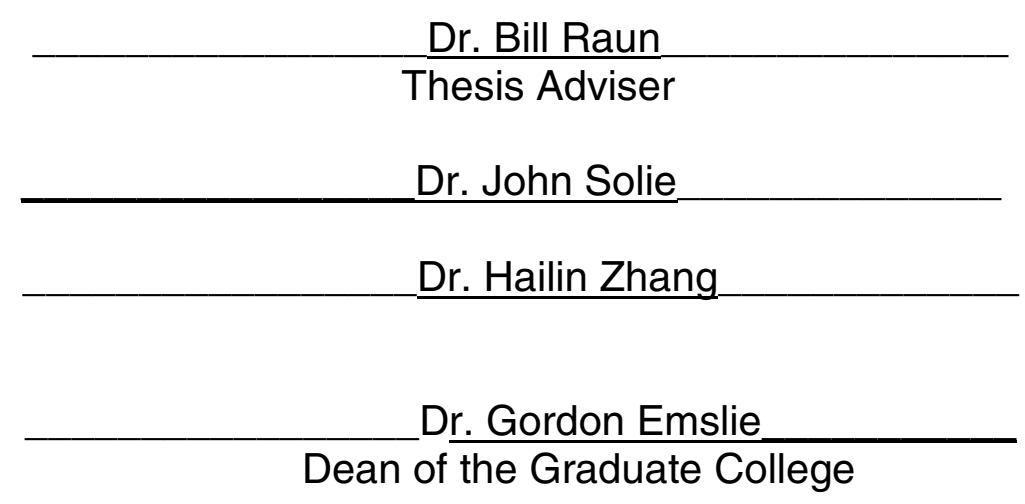




\section{ACKNOWLEDGMENTS}

I would first like to thank Oklahoma State University, the Department of Plant and Soil Sciences and the Soil Fertility project for the support in completing this step in my education. I would also like to express a great deal of thanks to my advisor Dr. Raun for his leadership, knowledge, expertise, and guidance throughout this project and the ability to work on many projects in this field. I would also like to thank my committee members, Dr. John Solie and Dr. Hailin Zhang, for their knowledge and expertise. I also would like to thank all of the soil fertility students and employees which includes, Dr. Kyle Freeman, Dr. Roger Teal, Dr. Kefyalew Girma, Brian Arnall, Brenda Tubana, Clint Mack, Chung Byungkyun, Olaga Walsh, Starr Holtz, Clint Dotson, Pam Turner, and Brandon England for all the field help and the memories that will never be forgotten.

I would like to give a special thanks to my family and friends for being there for what ever I have needed through my educational career and helping me with problems that I could not have resolved by myself. Finally, I would like to thank my wife for supporting and helping me during hard times. Last but not least, I would like to thank God for giving me the strength and determination to complete this step in my education. 
TABLE OF CONTENTS

Chapter

Page

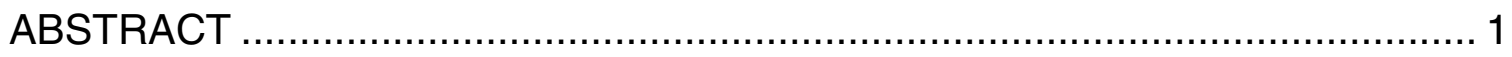

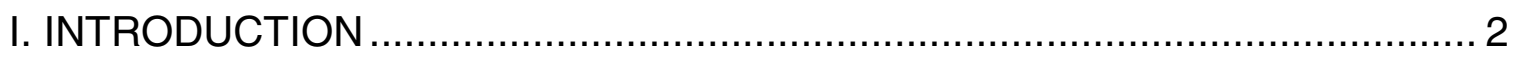

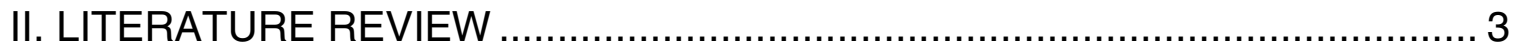

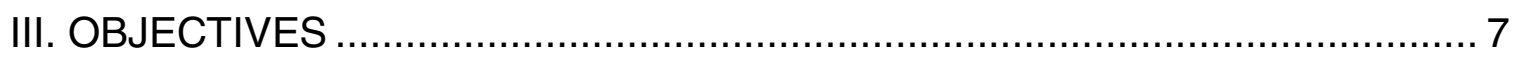

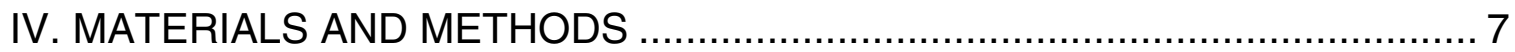

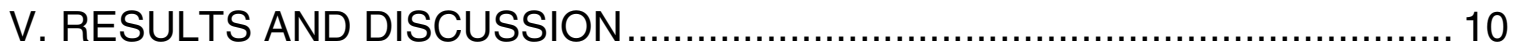

GRAIN YIELD BY PLANT IN 3 PLANT SEQUENCE …........................... 10

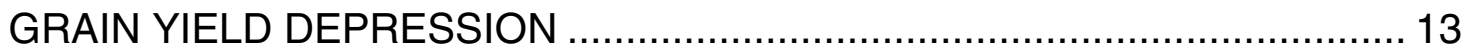

PERCENT OF MAXIMUM CORN GRAIN YIELD ...................................... 14

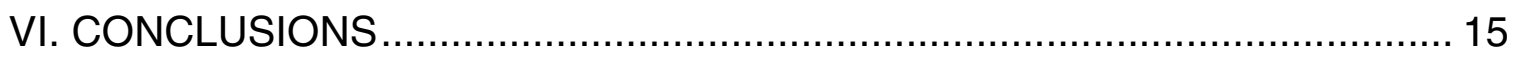

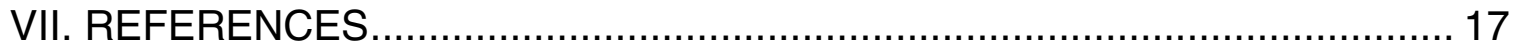




\section{LIST OF TABLES}

Table

Page

1. Initial surface $(0-30.48 \mathrm{~cm})$ soil test results prior to experiment initiation at Efaw and Lake Carl Blackwell (LCB) OK......................................... 19

2. Treatment structure employed at Lake Carl Blackwell, and EFAW, 2005 and 2006 evaluating delayed planting on resultant corn grain yields.

3. Analysis of variance for corn grain yield as influenced by days of delayed planting, and $\mathrm{N}$ rate, Efaw and Lake Carl Blackwell, 2005 and 2006......... 20

4. Treatment, preplant N, Days delay, planting, Mean grain yields for Efaw, Lake

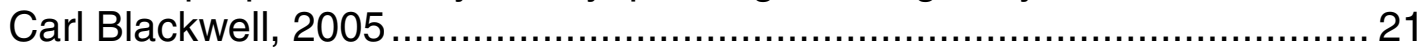


Figure

\section{LIST OF FIGURES}

1. Planting device constructed to establish fixed depths, and distances between plants for all sites, 2005-2006

2. Schematic diagram demonstrating a single plot whereby the center row had 5 , 3-plant sequences between two border rows. Each treatment was replicated three times, thus, 15, 3-plant sequences were used to determine each treatment average.

3. Three plant sequence where \#2 was planted $0,2,5,8$, and 12 days later, 56 $\mathrm{kg} \mathrm{N}$ ha-1 applied preplant, Efaw 2005 (each point represents the average of nine plants repeated in these 3-plant sequences).

4. Three plant sequence where \#2 was planted $0,2,5$, 8, and 12 days later, 168 $\mathrm{kg} \mathrm{N}$ ha-1 applied preplant, Efaw 2005 (each point represents the average of nine plants repeated in these 3-plant sequences).

5. Three plant sequence where \#2 was planted $0,2,5,8$, and 12 days later, 56 kg N ha-1 applied preplant, Lake Carl Blackwell 2005 (each point represents the average of nine plants repeated in these 3-plant sequences). 24

6. Three plant sequence where \#2 was planted $0,2,5,8$, and 12 days later, 168 kg N ha-1 applied preplant, Lake Carl Blackwell 2005 (each point represents the average of nine plants repeated in these 3-plant sequences). 24

7. Three plant sequence where \#2 was planted $0,2,5,8$, and 12 days later, 56 $\mathrm{kg} \mathrm{N}$ ha-1 applied preplant, Efaw 2006 (each point represents the average of nine plants repeated in these 3-plant sequences).

8. Three plant sequence where \#2 was planted $0,2,5$, 8, and 12 days later, 168 $\mathrm{kg} \mathrm{N}$ ha-1 applied preplant, Efaw 2006 (each point represents the average of nine plants repeated in these 3-plant sequences). 25

9. Three plant sequence where \#2 was planted $0,2,5,8$, and 12 days later, 56 kg N ha-1 applied preplant, Lake Carl Blackwell 2006 (each point represents the average of nine plants repeated in these 3-plant sequences). 26 
10. Three plant sequence where \#2 was planted $0,2,5,8$, and 12 days later, 168 kg N ha-1 applied preplant, Lake Carl Blackwell 2006 (each point represents the average of nine plants repeated in these 3-plant sequences). 26

11. Corn grain yield depression in $\mathrm{kg} \mathrm{ha}^{-1}$ when the center plant was delayed 0 , 2, 5, 8, and 12 days, Efaw 2005.

12. Corn grain yield depression in $\mathrm{kg} \mathrm{ha}^{-1}$ when the center plant was delayed 0 , 2, 5, 8, and 12 days, Efaw 2006

13. Corn grain yield depression in $\mathrm{kg} \mathrm{ha}^{-1}$ when the center plant was delayed 0 , 2, 5, 8, and 12 days, LCB 2005.

14. Corn grain yield depression in $\mathrm{kg} \mathrm{ha}^{-1}$ when the center plant was delayed 0 , 2, 5, 8, and 12 days, LCB 2006.

15. Three plant average when the center plant was delayed $0,2,5,8$, and 12 days expressed as percent of maximum corn grain yields, Efaw 2005

16. Three plant average when the center plant was delayed $0,2,5,8$, and 12 days expressed as percent of maximum corn grain yields, Efaw 2006...... 29

17. Three plant average when the center plant was delayed $0,2,5,8$, and 12 days expressed as percent of maximum corn grain yields, LCB 2005.

18. Three plant average when the center plant was delayed $0,2,5,8$, and 12 days expressed as percent of maximum corn grain yields, LCB 2006. 


\title{
EFFECT OF DELAYED EMERGENCE ON CORN (ZEA MAYS L.) GRAIN YIELDS
}

\begin{abstract}
Crops with uniform stands have the advantage of producing higher grain yield under good growing conditions and management systems than crops with poor stands. Delayed emergence and complete failure of seed emergence are causes of uneven crop stand early in the season. The objectives of this study were to determine corn (Zea mays L.) grain yield reduction as a function of interplant competition arising from delayed emergence and to evaluate yield levels associated with 3 plant sequences, with and without delayed emergence. These variables were investigated at two experimental sites established in the spring of 2005, near Stillwater, OK at the Lake Carl Blackwell Agronomy Research Farm under irrigation and at the Efaw Agronomy Research Farm in a rain-fed environment. Pioneer (33B51) Bt corn hybrid was planted late March or early April at a seeding rate of 73779 plants ha ${ }^{-1}$. Each 2.7 m-row was planted by hand to maintain $18 \mathrm{~cm}$ inter-row spacing. A total of 15 plants within a row were divided into five subgroups. Each subgroup contained three plants, two plants planted on the same day and a delayed plant planted between the two plants. The delayed plants were planted 2, 5, 8, 12 days after the initial planting (to simulate various delayed emergence scenarios). At the irrigated site, 2-year average grain yields decreased when the center plant of three plants seeding
\end{abstract}


date was delayed $2,5,8$, and 12 days, by $3,10,19$ and $25 \%$, respectively. At the rainfed site, average grain yields decreased when the center plant of three plants was delay planted at $2,5,8$, and 12 days, by $14,25,23$, and $11 \%$, respectively. This suggests that the overall effects of delayed planting (emergence) on resultant grain yields were greater where irrigation was not available. Over both sites and years, for each day delay emergence (estimated using delayed planting), grain yield depression could be expected to exceed 225 $\mathrm{kg} \mathrm{ha}^{-1}$ using the slope components reported at each site.

\section{Introduction}

Delayed emergence research can provide farmers with the tools needed to produce higher crop yields. Limited research has been done that looks at days delayed at the by-plant level; this study will. Profit and the environment are two important issues to the majority of corn producers. To maintain these at acceptable levels, yield should be optimized using modest amounts of agricultural inputs. It is well documented that crop stand is important in determining final grain yield (Evans and Fisher, 1999; Tollenaar and Wu, 1999). Crops with uniform stands have the advantage of producing higher grain yield under good growing conditions and management systems than crops with poor stands. Thus for farmers, replanting is necessary for stands they visually evaluated as poor before further investment in fertilizer, herbicide and irrigation. So what can farmers do to homogenize plant stands? Maybe they could drive slower and at a constant speed, or they could better prepare the seed bed. 
Delayed emergence and complete failure of seed emergence are causes of uneven crop growth early in the season. This behavior can be attributed to irregular planting depth, seed quality, soil compaction, and limited moisture (Ford and Hicks, 1992; Dwyer et al. 1999). Murungu (2003) found that seed priming (soaking seeds in water before planting) improved emergence and early growth in drying soils. Harris et al. (1999) also concluded that there was a direct benefit in faster emergence, better stands and a lower incidence of re-sowing. A study by Triplet and Tesar (1960) showed that improved emergence of alfalfa seedlings was attributed to increased soil water and seed-contact as a result of increased planting depth from 0 to 1 inches and soil compaction. Despite improved agricultural practices and land management, complete eradication of seed emergence related problems is still not achievable. There have been numerous studies done on the causes of delayed emergence although there has not been much on the effect of delayed emergence on corn grain yields. This could be useful in variable rate application in corn.

\section{Literature Review}

Nitrogen use efficiency (NUE) in cereal crop production is currently $33 \%$ worldwide with an estimated average of $29 \%$ and $42 \%$ for the developing and the developed countries, respectively (Raun and Johnson, 1999). These low NUE values can be attributed to plant nitrogen $(\mathrm{N})$ loss by $\mathrm{NH}_{3}$ (Francis et al, 1993), $>10 \%$ denitrification loss (Hilton et al., 1994), $N$ fertilizer applied in excess of crop needs (Johnson and Raun, 1995), and surface runoff of $\mathrm{N}$ fertilizer ranging between 1 and 13\% (Blevins et al.,1996 ; Chichester and Richardson, 1992). A 
$1 \%$ global increase in NUE would result in an estimated savings of $\$ 234,658,462$ (Raun and Johnson, 1999).

The importance of improving NUE for the environment is explained by Dwivedi et al. (2003) and Cassman et al. (2002). Nitrogen use efficiency is important to the environment due to the run-off of $\mathrm{N}$ into fields and ponds affecting the water quality. Many studies showed that delayed plant emergence reduced yield, thus in theory if you could fertilize each plant individually you could increase NUE and reduce the cost of fertilizer. This would also help to reduce the impact of $\mathrm{N}$ on the environment. By finding out how many days plant emergence is delayed, you can identify which plants need to be fertilized and which ones do not and this could help to increase NUE.

Nielsen (2001) reported that plants that are next to a gap produced larger ears. Martin et al. (2005) found an average difference equivalent to $2765 \mathrm{~kg} \mathrm{ha}^{-1}$ plant to plant difference in corn yield. They further noted that production methods that homogenize plant stands and emergence, should decrease plantto-plant variation and will likely lead to increased yields. Plant spacing is important in precision farming. If there is a section that has plants that are crowded, they will produce smaller ears than a section that has bigger gaps in it. While plants near the gap produced larger ears, this did not compensate for the yield lost due smaller ears that were produced in the crowded sections (Nielsen 2001). If two plants are crowded, one being bigger and one being smaller, the smaller plant will likely compete less for sunlight and nutrients. In this case, the smaller plant will not be able to catch up resulting in a smaller ear at harvest 
(Nielsen, 2001). Nielsen (2001) further discussed the variability between plants in a row by using the term plant spacing variability (PSV). The PSV is the standard deviation of the plant spacing within a representative row in a field. Nielsen noted that in 350 production corn fields in Indiana and Ohio, 16\% had a PSV of three inches or less, $60 \%$ had a PSV of three to five inches, and $24 \%$ of the fields had a PSV of six inches or greater. Further research showed that for every one inch in PSV about $157 \mathrm{~kg} \mathrm{ha}^{-1}$ of yield loss occurred.

Nafziger et al. (1991) found that delayed emergence can reduce grain yields of corn from 6 to $22 \%$. Ford and Hicks (1992) concluded that delayed emergence is often caused by many factors such as environmental conditions (limited moisture, drier colder climate), as well as agricultural practices and land management (seed depth, soil compaction, and residue left on top of the seed).

Corn grain yields were reduced by $546 \mathrm{~kg} \mathrm{ha}^{-1}$ and $1179 \mathrm{~kg} \mathrm{ha}^{-1}$ with planting dates delayed 7 and 14 days respectively (Ford and Hicks 1992). They also observed reduced yields when non uniform (mixed) stands were simulated by planting corn plants at different distances within the row.

Imholte and Carter (1987) found that delayed planting decreased yields in both conventional and no-till corn systems; the highest corn grain yields of conventional and no-till achieved when planting was completed by early May. Alessi and Power (1971) observed that each $10 \mathrm{~mm}$ increase in planting depth delayed corn emergence for about one day at a constant temperature of $13.3^{\circ} \mathrm{C}$. They concluded that at least 68 growing degree days (GDD) with temperatures above $13.3^{\circ} \mathrm{C}$ and adequate soil moisture are necessary to achieve $80 \%$ 
emergence in corn. Lindstrom et al. (1976) showed that a combination of factors including water potential, the lowering of soil temperature from $25^{\circ} \mathrm{C}$, or with the increasing of planting depth decreased corn emergence rate. Grant and Buckle (1974) reported that adverse conditions may cause a reduction in plumule length. Helms et al. (1997) found that if soil water content is sufficient for germination and persists for 18 days after planting, emergence will not be reduced.

Temperature-Activated Polymer (TAP) is a seed coating that is designed to impede the water absorption to the seed until an adequate soil temperature is reached. Gesh and Archer (2005) found that $60-90 \%$ of TAP coated seeds emerged where only $49-68 \%$ of uncoated seeds emerged. TAP protects the seeds from extended cold soil temperatures and helps with emergence.

Lithourgidis et al. (2005) noted that delayed emergence and reduced plant populations are problems associated with corn production in conservation tillage. They also found that when soil moisture levels were sufficient, the emergence rate did not differ in conventional till and no-till systems. Dry soil conditions, however, were associated with a 16\% decrease in emergence in no-till corn. They found that there was no significant difference in delayed plants in reduced till, and they noted that the presence of delayed plants did not reduce silage yield in no-till systems. Seedling emergence 2 to 3 weeks after planting was lower in no-till, compared to conventional till and reduced-till (Burgess et al. 1996).

Drury et al. (1999) found that red clover (Trifolium pretence L.) helped with some of the problems associated with corn production in no-till practices. They found that notill increased soil water by 2 to $5 \%$ and reduced soil temperature by 1 to $2^{\circ}$ which was 
expected to decrease emergence. Corn emergence in no-till was shortened by 3 to 4 days without red clover as a cover crop and the total plant stand was reduced by $24 \%$ compared with conventional tillage.

Graven and Carter (1991) found that emergence rate strongly depends on the corn seed quality. They observed a 4 to $6 \%$ decrease in emergence associated with medium and low seed quality, and that lower seed quality decreased emergence when fields were planted earlier. When planting date was delayed, seed quality did not have a significant effect on emergence. In late planted fields seed quality did not have an effect on emergence. With low and medium quality seed they found a 1 day delayed emergence compared to high quality seed. Graven and Carter (1990) found that seed size and shape had an effect on emergence. They achieved higher emergence rates with large flat and small round seeds compared to large round and small flat seeds under temporal and moisture stress environments.

\section{Objectives}

The objectives of this study were: I. determine corn grain yield reduction as a function of interplant competition arising from delayed emergence; and II. evaluate yield levels associated with 3 plant sequences, with and without delayed emergence.

\section{Materials and Methods}

Two experimental sites established in the spring 2005: one near Perry, OK at the Lake Carl Blackwell irrigated research station, and one at Efaw Research Station, near Stillwater, OK. Lake Carl Blackwell research station soil series is a 
Pulaski fine sandy loam (Fine Sandy Loam, Coarse-loamy, mixed, nonacid, thermic Typic Ustifluvent) and Efaw Research Station has a soil series of Easpur loam (fine-loamy, mixed, superactive, thermic Fluventic Haplustoll). Results from composite pre-plant soil sample analysis at each site are reported in Table 1.

Pioneer (33B51) Bt corn hybrid was planted late March or early April at a seeding rate of 73779 seeds $/$ ha. With corn planted at $76.2 \mathrm{~cm}$ row spacing, the distance between plants is $17.8 \mathrm{~cm}$. This $17.8 \mathrm{~cm}$ seed spacing was achieved by hand planting. Equal inter-row spacing is essential for the analysis of this experiment; therefore each row was planted by hand.

A planting device was made from $3.81 \mathrm{~cm}$ square tubing to make sure that the planting depth of $5.08 \mathrm{~cm}$ and spacing $(17.78 \mathrm{~cm}$ apart) was achieved. Bolts positioned $0.95 \mathrm{~cm}$ deep where every $17.78 \mathrm{~cm}$ apart along the tube. This was then used to create fixed depressions in the soil and ensuring specific planting points for each of the seeds (Figure 1).

The experiment employed a randomized complete block design (RCBD) with 11 treatments and 3 replications. The treatment structure is reported in Table 2. Each row contained 15 plants in total. From the total number of plants there were five subgroups. Each subgroup contained three plants, two plants planted on the same day and a delayed plant planted in the middle of the two plants. The delayed plants were planted on a specific day 2, 5, 8, and 12 days (to simulate various delayed emergence scenarios). Each plot consisted of 1 row that was hand planted with 1 border row on each side. Row, and plant configuration are illustrated in Figure 2. Border rows were machine planted on 
the same day on each side of the rows which contained the delayed plants at a similar population. For each treatment a total of 153 -plant sequences were evaluated. Because in some cases, plants did not emerge at all, or damage was incurred from insects and/or other factors, only 9 of the 3-plant sequences were used for treatment averages. Each plant occupied $0.13548 \mathrm{~m}^{2}$, thus yield expressed in $\mathrm{kg} \mathrm{ha}^{-1}$ was determined by divided the collected values in grams per plant by 0.13548 , then multiplied by 10 to obtain $\mathrm{kg} \mathrm{ha}^{-1}$.

Two preplant nitrogen fertilizer rates (56 and $168 \mathrm{~kg} \mathrm{ha}^{-1}$ ) were applied broadcast before planting using urea (46-0-0). Bicep Lite II Magnum® Syngenta (Greensboro, North Carolina) was applied preplant at a rate of $2338 \mathrm{ml} / \mathrm{ha}$ to control broadleaf weeds and grasses at each site.

The groups were tagged in sets of three plants and were hand harvested. In each treatment three of the five subgroups were selected for harvest. For each of the three subgroups, each plant was harvested and bagged separately. Each bag was individually weighed wet, dried in an air forced oven at $66^{\circ} \mathrm{C}$ and weighed again for moisture determination. Percent moisture was determined by taking the wet weight minus the dry weight and dividing by the wet weight. Grain yield for all treatments was expressed using $15.5 \%$ moisture. Analysis of variance to determine treatment effects were determined using SAS (2002) significant differences between treatments was determined using the standard error of the difference (SED) between two equally replicated means. 


\section{Results and Discussion}

Analysis of variance reporting the significance of treatment effects on corn grain yield (average of the 9, 3-plant sequences) is reported in Table 3. The main effect of treatment was significant at the 0.05 level or less for both years at both locations. Even though planting depth, method of planting, and seed cover/compaction were held constant, there were minor discrepancies concerning emergence. Data was not collected documenting exact day of emergence for all 9, 3-plant sequences that comprised individual treatments, but the large number of sub-sets collected was expected to deliver accurate and precise estimates of the average (yield, yield depression, and/or percent of maximum grain yield).

Averaged over years, grain yields decreased when the center plant of three plants was delay planted at 2, 5, 8, and 12 days, by $3,10,19$ and $25 \%$, respectively (Table 4). For the rainfed site, average grain yields decreased when the center plant of three plants was delay planted at $2,5,8$, and 12 days, by 14 , 25,23 , and $11 \%$, respectively. In terms of percent yield reduction, the overall effects of delayed planting (emergence) on resultant grain yields were greater where irrigation was not available.

\section{Grain Yield by Plant in 3 Plant Sequence}

Grain yields for each plant (average of 9, 3-plant sequences) where plants 1 and 3 were planted at the same time, and plant 2 was delay planted by 2, 5, 8, and 12 days are reported in Figures 3-10 for Efaw and Lake Carl Blackwell, with 56 and $168 \mathrm{~kg} \mathrm{~N} \mathrm{ha}^{-1}$ applied preplant in both 2005 and 2006, respectively. The 
standard error of the difference between two equally replicated means (SED) is reported on each graph (Figures 3-10). No differences in grain yield were found in the 3 plant sequences when planted on the same day at Efaw, 2005 for the 56 $\mathrm{kg} \mathrm{N} \mathrm{ha}^{-1}$ rate (Figure 3). However, when delayed by 2 or more days, the center plant had significantly lower yields, and the yield reduction exceeded $2000 \mathrm{~kg} \mathrm{ha}^{-}$

1 . These yield reductions were primarily due to a center plant not producing when averaged over the 3 plant sequences. It is important to note that there were also yield reductions in the border plants when the center plant was delay planted by 2, 5, and 8 days (compared to no delay). However, for the 12 day delay the center plant had significantly lower yields but the border plants yields tended to be higher than 2,5 , and 8 day. This suggests that at 2,5 , and 8 days the center plant competed with the border plants, but for the 12 day delay there was less competition since border plants yielded slightly more.

At the $168 \mathrm{~kg} \mathrm{~N} \mathrm{ha}^{-1}$ rate, at Efaw in 2005, results were highly variable, especially when noting the depression in yield for plant \#2 when no delay was imposed (Figure 4). It is likely that the 2, 5 and 8 delay could have increased yields because competition between the plants was less. This may have been caused by the high seeding rate used at this rainfed site. In other words there was likely less competition between plants, at this high $\mathrm{N}$ rate, evidenced in the higher yields when compared to those at the $56 \mathrm{~kg} \mathrm{~N} \mathrm{ha}^{-1}$ rate (Figure 3 versus Figure 4).

Results at LCB in 2005 for the 56 and $168 \mathrm{~kg} \mathrm{~N} \mathrm{ha}^{-1}$ rates (Figures 5 and 6), similar trends were observed as that reported for Efaw. However, at this site, 
there was no significant effect of delay planting by 2 days at the $56 \mathrm{~kg} \mathrm{~N} \mathrm{ha}^{-1}$ rate. By 5 days, the center plant had significantly lower yields versus the 0 and 2 day delay sequence (Figure 5). At the $168 \mathrm{~kg} \mathrm{~N} \mathrm{ha}^{-1}$ rate the 2 and 5 day delayed plants were not different from the 0-day delay treatment. By applying more $\mathrm{N}$, the 5 day delay was in effect not different from the 0 and 2 day delay treatments, yet at the low $\mathrm{N}$ rate the yield decrease was notable (Figures 5 and 6). It is not biologically understood as to exactly why this happened.

Results for the Efaw site in 2006 at the 56 and $168 \mathrm{~kg} \mathrm{~N} \mathrm{ha}^{-1}$ rates are reported in Figures 7 and 8, respectively. Extreme temperatures was encountered throughout the season at this site, and as a result, yields were highly variable. In general, limited differences were noted for the $0,2,5$, and 8 day delays at the $56 \mathrm{~kg} \mathrm{~N} \mathrm{ha}^{-1}$ rate (Figure 7). By the 12 day delay, the center plant yielded significantly less than the border plants. Furthermore, the two non delayed plants for the 12 day delay tended to have higher yields when compared to the 0,5 , and 8 day delayed plantings. At the $168 \mathrm{~kg} \mathrm{~N} \mathrm{ha}^{-1}$ rate, yields were higher and the separation of yields due to treatment was wider (Figure 8). The more the center plant was delayed the greater the yield reduction was when compared to the two non-delayed plants.

In 2006 at LCB the 56 and $168 \mathrm{~kg} \mathrm{~N} \mathrm{ha}^{-1}$ rates (Figures 9 and 10, respectively) resulted in highly variable treatment results. At the $56 \mathrm{~kg} \mathrm{~N} \mathrm{ha}^{-1}$ rate, the 8 and 12 day delayed planting had lower yields for the center plant. At the $168 \mathrm{~kg} \mathrm{~N} \mathrm{ha}^{-1}$ rate, yields were higher, but more variable. The center plants for the 8 and 12 day delayed planting tended to have lower yields while the 
border plants had higher yields, similar to results for Efaw in 2005 and 2006. As was noted for Efaw in 2006, the severe heat contributed to the variable yield results at LCB. The high temperate occurred during flowering which further depressed final grain yield results due to incomplete pollination.

\section{Grain Yield Depression, kg/ha}

Grain yield depression is reported as a function of planting delay in days for Efaw and Lake Carl Blackwell in 2005 and 2006 in Figures 11-14, respectively. At Efaw in 2005 (Figure 11) the grain yield depression increased significantly as planting was delayed from 2 to 12 days. As has been noted, the delayed planting was used to simulate delayed emergence.

At Efaw in 2005, when the planting delay was 5 days grain yield reduction was estimated to exceed $2400 \mathrm{~kg} \mathrm{ha}^{-1}$ predicted by the linear relationship (Figure 11). With 8 and 12 day delay the grain yield depression exceeded $3000 \mathrm{~kg} \mathrm{ha}^{-1}$, for both $\mathrm{N}$ rates.

In 2006 at Efaw (Figure 12), the grain yield depression as a function of delayed planting was actually greater for both $\mathrm{N}$ rates, noting the increased slope when compared to the 2005 data (Figure 12 versus Figure 11). However, for 2006, limited differences were noted between the 2 and 5 day delay planting (Figure 12). This trend was generally similar for the 56 and $168 \mathrm{~kg} \mathrm{~N} \mathrm{ha}^{-1}$ rates.

At LCB in 2005 , the grain yield depression was highly significant as a function of planting delay, more so than that observed at the other sites and/or years (Figure 13). This was partly due to the increased yield levels recorded at LCB in 2005. However, in 2006, the effect of planting delay on grain yield 
depression was less significant, partly due to the lower yields encountered in this heat stressed year (Figure 14).

Over both sites and years, for each day of delay emergence (estimated using delayed planting), grain yield depression could be expected to exceed 225 $\mathrm{kg} \mathrm{ha}^{-1}$ using the slope components reported at each site (Figures 11-14).

\section{Percent of Maximum Corn Grain Yield}

The percent of maximum corn grain yield expressed as a function of planting delay in days for Efaw and Lake Carl Blackwell, in 2005 and 2006 are reported in Figures 15-18, respectively. At Efaw in 2005 the percent of maximum grain yield was reduced by 3 and $15 \%$ at the 56 and $168 \mathrm{~kg} \mathrm{~N} \mathrm{ha}^{-1}$ preplant rates, respectively when delayed planting took place at 2 days (Figure 15). Percent of maximum corn grain yield continued to decline gradually when the delay went from 2 to 8 days. By the 12 day delay, grain yields were significantly reduced beyond that seen for the 2, 5, and 8 day delayed planting (Figure 15). This relationship between percent of maximum corn grain yield and planting delay was much clearer at Efaw in 2006, whereby a distinct linear relationship was observed, and similar for both $\mathrm{N}$ rates (Figure 16). For the 12 day delay, the percent of maximum corn grain yield declined to less than $20 \%$ of the average of the 2 border plants (Figure 15).

At LCB in 2005 grain yields declined significantly in a linear fashion as planting was delayed from 2 to 12 days late (Figure 17). However, there was a trend for limited yield reduction when the center plant was only 2 days late. By 5 days, the percent maximum corn grain yield was estimated at 21 and $24 \%$ less 
using the linear function reported (Figure 17). In general, limited differences due to the fertilizer $\mathrm{N}$ rate were found at this site. In 2006 at LCB there were varying results due to the severe heat stress encountered from July 14 to August 18 when $>30$ consecutive above $37^{\circ} \mathrm{C}$ days were present (Figure 18). Despite the heat stress, the linear relationship of percent of maximum corn grain yield expressed as planting day delays were similar to that noted in 2005 (Figures 17 and 18).

\section{Conclusions}

Delayed planting to simulate delayed emergence was used in this experiment to determine the adverse effects on final corn grain yield. When comparing 3 plant sequences, the results show that delayed emerging plants result in decreased corn grain yields. Over both sites and years, data showed that when the days of delayed planting was greater than 5 days there was almost always a significant yield reduction. When looking at the three plant sequences the delayed plant by 2, 5, and 8 days continued to compete with the two non delayed plants. By 12 days these plants competed less with the two non delayed plants and that then tended to have higher by-plant yields. Results from this study will assist those groups interested in improving by-plant $\mathrm{N}$ fertilization by knowing how much a plant is delayed and how that ultimately affects final corn grain yields. This information will in turn be used to estimate $\mathrm{N}$ removal based on yield level (or projected yield decrease) based on how much each plant is or is not delayed versus neighboring plants. When evaluating both sites and years, 
for each day delay emergence (estimated using delayed planting), grain yield depression ranged from $225 \mathrm{~kg} \mathrm{ha}^{-1}$ to $1379 \mathrm{~kg} \mathrm{ha}^{-1}$. 


\section{References:}

Blevins D.W, D.H.W., B.P Kelly, and S.R Silva. 1996. Movement of nitrate fertilizer to glacial till and runoff from claypan soil. J. Environ. Qual. 25:584-593.

Burgess, M.S., G.R. Mehuys, and C.A. Madramootoo. 1996. Tillage and crop residue effects on corn production in Quebec. Agron. J. 88:792-797.

Cassman, K.G., A. Dobermann, and D.T. Walters. 2002. Agroecosystems, Nitrogen-use Efficiency, and Nitrogen Management. AMBIO: A Journal of the Human Environment 31:132-140.

Chichester, F.W., C.W. Richardson. 1992. Sediment and nutrient loss from clay soils as affected by tillage. J. Environ. Qual. 21:587-590.

Diaz-Zorita, M., J.H. Grove, and E. Perfect. 2005. Soil Fragment size distribution and compactive effort effects on maize root seedling elongation in moist soil. Crop Sci. 45:1417-1426.

Drury, C.F., C. Tan, T.W. Welacky, T.O. Oloya, A.S. Hamill, and S.E. Weaver. 1999. Red clover and tillage influence on soil temperature, water content, and corn emergence. Agron. J. 91:101-108.

Dwivedi, B.S., A.K. Shukla, V.K. Singh, and R.L. Yadav. 2003. Improving nitrogen and phosphorus use efficiencies through inclusion of forage cowpea in the rice-wheat systems in the Indo-Gangetic Plains of India. Field Crops Res. 80:167-193.

Evans, L.T., and R.A. Fischer. 1999. Yield Potential: Its Definition, Measurement, and Significance. Crop Sci 39:1544-1551.

Ford, J.H., and D.R. Hicks. 1992. Corn growth and yield in uneven emerging stands. J. Prod. Agric 5:185-188.

Francis. D.B., J.S.S., and M.F. Vigil. 1993. Post-anthesis nitrogen loss from corn. Agron. J. 85:659-663.

Gesch, R.W., and D.W. Archer. 2005. Influence of Sowing Date on Emergence Characteristics of Maize Seed Coated with a Temperature-Activated Polymer. Agron. J 97:1543-1550.

Graven, L.M., and P.R. Carter. 1990. Seed size/shape and tillage system effect on corn growth and grain yield. J.Prod. Agric. 3:445-452.

Graven, L.M., and P.R. Carter. 1991. Seed quality effect on corn performance under conventional and no-tillage systems. J. Prod. Agric. 4:366-373.

Gupta, S.C., E.C. Schneider, and J.B. Swan. 1988. Planting depth and tillage interactions on corn emergence. Soil Sci. Soc. Amer. 52:1122-1127.

Harris, D., Joshi, A., Khan, P.A., Gothkar, P., Sodhi, P.S.,. 1999. On-farm seed priming in semi-arid agriculture: development and evaluation in maize, rice, and chickpea in India using participatory methods. Exp. Agric. 35:1529. 
Helms, T.C., E.L. Deckard, and P.A. Gregoire. 1997. Corn, sunflower, soybean emergence influenced by soil temperature and soil water content. Agron. J.:59-63.

Hilton, B.R., P.E. Fixen, and H.J. Woodard. 1994. Effects of tillage, nitrogen placement, and wheel compaction on denitrification rates in the corn cycle of corn-oats rotation. J. Plant Nutr. 17:1341-1357.

Lithourgidis, A.S., C.A. Tsatsarclis, and K.V. Dhima. 2005. Tillage effects on corn emergence, sillage yield and labor and fuel inputs in double cropping with wheat. Crop Sci. 45:2523-2529.

Liu, W., M. Tollenaar, G. Stewart, and W. Deen. 2004. Crop ecology, management \& quality: Response of corn grain yield to spatial and temporal variability in emergence. Crop Sci. 44:847-854.

Martin, K.L., P.J. Hodgen, K.W. Freeman, R. Melchiori, D.B. Arnall, R.K. Teal, R.W. Mullen, K. Desta, S.B. Phillips, J.B. Solie, M.L. Stone, O. Caviglia, F. Solari, A. Bianchini, D.D. Francis, J.S. Schepers, J.L. Hatfield, and W.R. Raun. 2005. Plant-to-Plant Variability in Corn Production. Agron. J 97:1603-1611.

Murungu, F.S., P. Nyamugafata, C. Chiduza, L.J. Clark, and W.R. Whalley. 2003. Effects of seed priming, aggregate size and soil matric potential on emergence of cotton and maize. Soil \& Tillage Research, 74:161-168

Nafziger, E.D., P.R. Carter, and E.E. Graham. 1991. Response of corn to uneven emergence. Crop Sci. 31:811-815.

Nielsen, R.L.B. 2001. Stand Establishment Variability in Corn. Dept. of Agronomy publication \# AGRY-91-01 Purdue University, West Lafayette, IN.

Raun.R W, G.V. Johnson. 1995. Soil-Plant Buffering of inorganic Nitrogen in Continuous Winter Wheat. Agron. J. 87:827-834.

Raun.R W, G.V.Johnson. 1999. Improving Nitrogen Use Efficiency for Cereal Production. Agron. J. 91:347-351.

SAS Institute. 2002. The SAS system for windows version 8.0. SAS Institute Inc., Cary, NC.

Tollenaar, M., and J. Wu. 1999. Yield Improvement in Temperate Maize is Attributable to Greater Stress Tolerance. Crop Sci 39:1597-1604.

Triplett, G.B., Jr., and M.B. Tesar. . 1960. Effects of compaction, depth of planting, and soil moisture tension on seedling emergence of alfalfa. Agron. J. 52:681-684. 
Table 1. Initial surface $(0-30.48 \mathrm{~cm})$ soil test results prior to experiment initiation at Efaw and Lake Carl Blackwell (LCB) OK.

\begin{tabular}{|c|c|c|c|c|c|c|c|}
\hline Location, depth & $\mathrm{K} \mathrm{mg} / \mathrm{kg}$ & $\begin{array}{l}\mathrm{P} \\
\mathrm{mg} / \mathrm{kg}\end{array}$ & $\begin{array}{l}\mathrm{NH} 4-\mathrm{N} \\
\mathrm{mg} / \mathrm{kg}\end{array}$ & $\begin{array}{l}\text { NO3-N } \\
\mathrm{mg} / \mathrm{kg}\end{array}$ & $\begin{array}{l}\text { Nitrogen } \\
\mathrm{g} / \mathrm{kg}\end{array}$ & $\begin{array}{l}\text { Carbon } \\
\mathrm{g} / \mathrm{kg}\end{array}$ & $\mathrm{pH}$ \\
\hline EFAW S. $0-15.24$ & 99 & 22 & 9 & 3.5 & 0.72 & 10.69 & 5.05 \\
\hline EFAW S. $15.24-30.48$ & 76 & 17 & 16 & 4.3 & 0.65 & 10.23 & 5.71 \\
\hline EFAW N. 0-15.24 & 105 & 20 & 17 & 3.2 & 0.64 & 10.93 & 6.15 \\
\hline EFAW N. 15.24-30.48 & 76 & 19 & 11 & 3.7 & 0.57 & 9.09 & 6.56 \\
\hline _CB SW. 0-15.24 & 144 & 45 & 28 & 4.3 & 0.77 & 9.87 & 5.63 \\
\hline
\end{tabular}

$\mathrm{NH}_{4}-\mathrm{N}$ and $\mathrm{NO}_{3}-\mathrm{N}-2 \mathrm{M} \mathrm{KCL}$ extract; $\mathrm{P}$ and $\mathrm{K}-$ Mehlich-3 extraction; $\mathrm{pH}-1: 1$ soil:deionized water

Table 2. Treatment structure employed at Lake Carl Blackwell, and EFAW, 2005 and 2006 evaluating delayed planting on resultant corn grain yields.

\begin{tabular}{|c|c|c|}
\hline Treatment No. & Delay in planting & N rate, $\mathrm{kg} \mathrm{ha}^{-1}$ \\
\hline 1 & All 3 plants planted on the same day & 0 \\
\hline 2 & All 3 plants planted on the same day & 56 \\
\hline 3 & Middle plant planted 2 days late & 56 \\
\hline 4 & Middle plant planted 5 days late & 56 \\
\hline 5 & Middle plant planted 8 days late & 56 \\
\hline 6 & Middle plant planted 12 days late & 168 \\
\hline 7 & All 3 plants planted on the same day & 168 \\
\hline 8 & Middle plant planted 2 days late & 168 \\
\hline 9 & Middle plant planted 5 days late & 168 \\
\hline 10 & Middle plant planted 8 days late & 168 \\
\hline 11 & Middle plant planted 12 days late & \\
\hline
\end{tabular}


Table 3. Analysis of variance for corn grain yield as influenced by days of delayed planting, and N rate, Efaw and Lake Carl Blackwell, 2005 and 2006.

Source of variation df Mean Squares

Efaw 2005

Rep

Treatment

Error

Efaw 2006

Rep

Treatment

Error

LCB 2005

Rep

Treatment

Error

LCB 2006

Rep

Treatment

Error
1756683

$6202754^{*}$

1953488

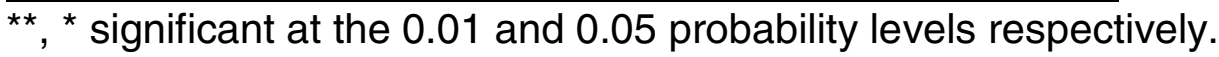


Table 4. Treatment, preplant N, Days delay, planting, Mean grain yields for Efaw, Lake Carl Blackwell, 2005

\begin{tabular}{|c|c|c|c|c|c|c|c|c|}
\hline \multirow[b]{2}{*}{ Treatment } & \multirow{2}{*}{$\begin{array}{l}\begin{array}{l}\text { Preplant } \\
\mathrm{N}\end{array} \\
\mathrm{kg} \mathrm{ha}^{-1}\end{array}$} & \multirow{2}{*}{$\begin{array}{l}\text { Days } \\
\text { Delay }\end{array}$} & \multicolumn{4}{|c|}{$\begin{array}{l}\text { Mean grain yields } \\
\mathrm{kg} \mathrm{ha}^{-1}\end{array}$} & \multirow[b]{2}{*}{$\begin{array}{l}\text { LCB } \\
2006 \\
\end{array}$} & \multirow[b]{2}{*}{ Avg. } \\
\hline & & & $\begin{array}{l}\text { Efaw } \\
2005 \\
\end{array}$ & $\begin{array}{l}\text { Efaw } \\
2006 \\
\end{array}$ & Avg. & $\begin{array}{l}\text { LCB } \\
2005 \\
\end{array}$ & & \\
\hline 1 & 0 & 0 & 4095 & 4010 & 4053 & 15579 & 2146 & 8863 \\
\hline 2 & 56 & 0 & 9084 & 6326 & 7705 & 16058 & 5021 & 10540 \\
\hline 3 & 56 & 2 & 5830 & 7443 & 6637 & 16805 & 3691 & 10248 \\
\hline 4 & 56 & 5 & 6233 & 5222 & 5728 & 15251 & 3904 & 9578 \\
\hline 5 & 56 & 8 & 6653 & 5265 & 5959 & 13614 & 3549 & 8582 \\
\hline 6 & 56 & 12 & 7109 & 6705 & 6907 & 11173 & 4618 & 7896 \\
\hline 7 & 168 & 0 & 9653 & 11532 & 10593 & 15130 & 5476 & 10303 \\
\hline 8 & 168 & 2 & 11307 & 9141 & 10224 & 16118 & 6404 & 11261 \\
\hline 9 & 168 & 5 & 11564 & 10717 & 11141 & 16361 & 5636 & 10999 \\
\hline 10 & 168 & 8 & 11581 & 10241 & 10911 & 11676 & 6999 & 9338 \\
\hline 11 & 168 & 12 & 10476 & 9329 & 9903 & 11674 & 6156 & 8915 \\
\hline SED & & & 1051 & 2049 & & 1178 & 1141 & \\
\hline
\end{tabular}

SED - standard error of the difference between two equally replicated means 


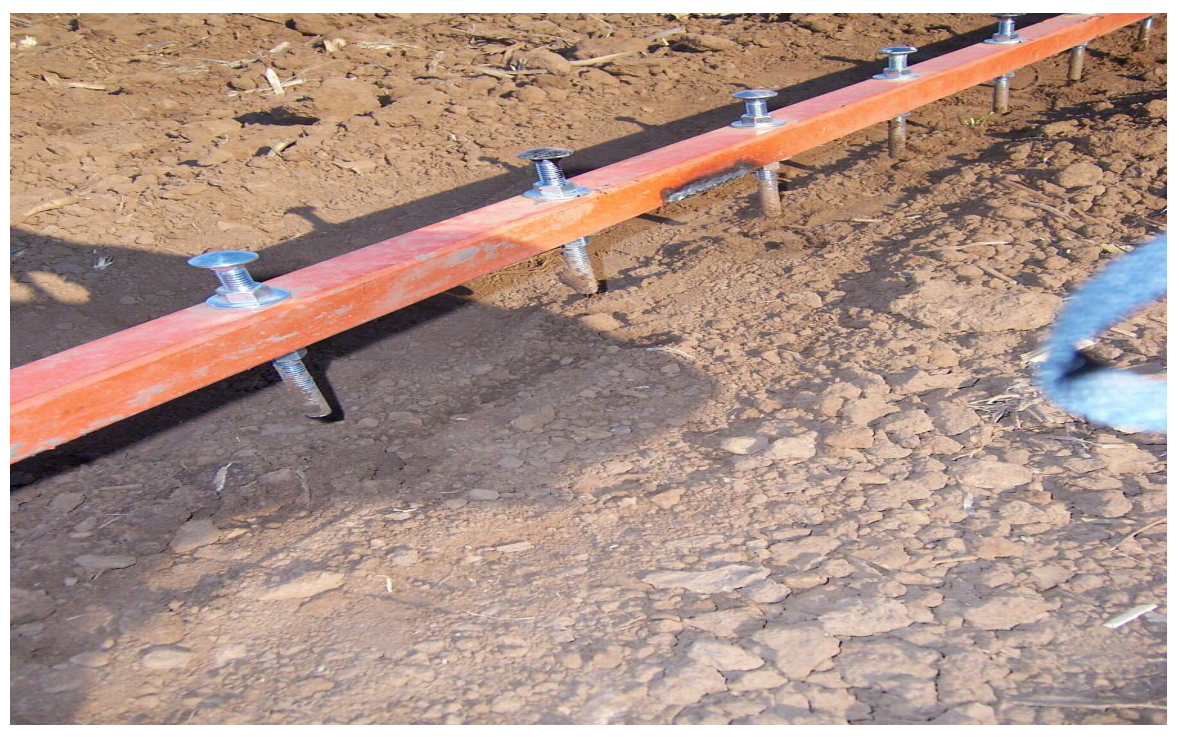

Figure 1. Planting device constructed to establish fixed depths, and distances between plants for all sites, 2005-2006.

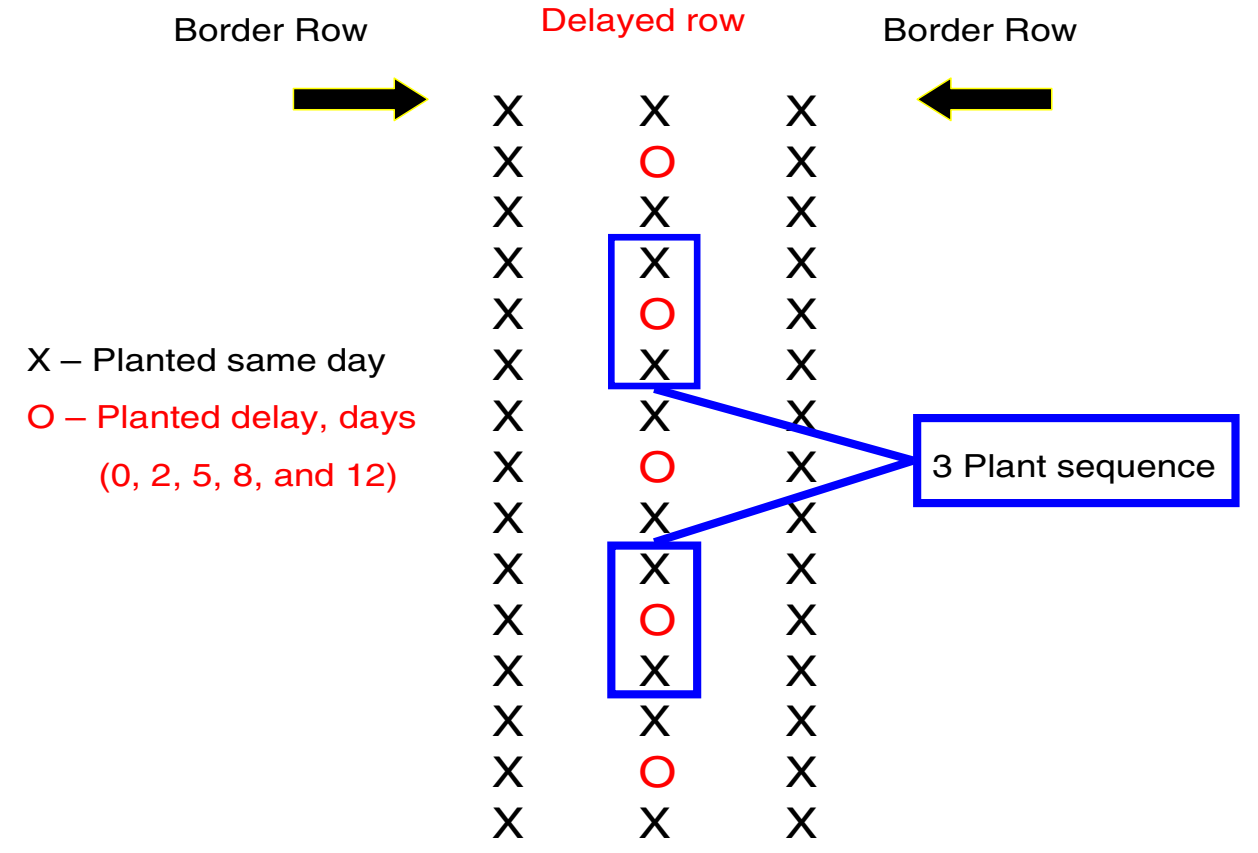

Figure 2. Schematic diagram illustrating a single plot whereby the center row had 5, 3-plant sequences between two border rows. Each treatment was replicated three times, thus, 15, 3-plant sequences were used to determine each treatment average. 


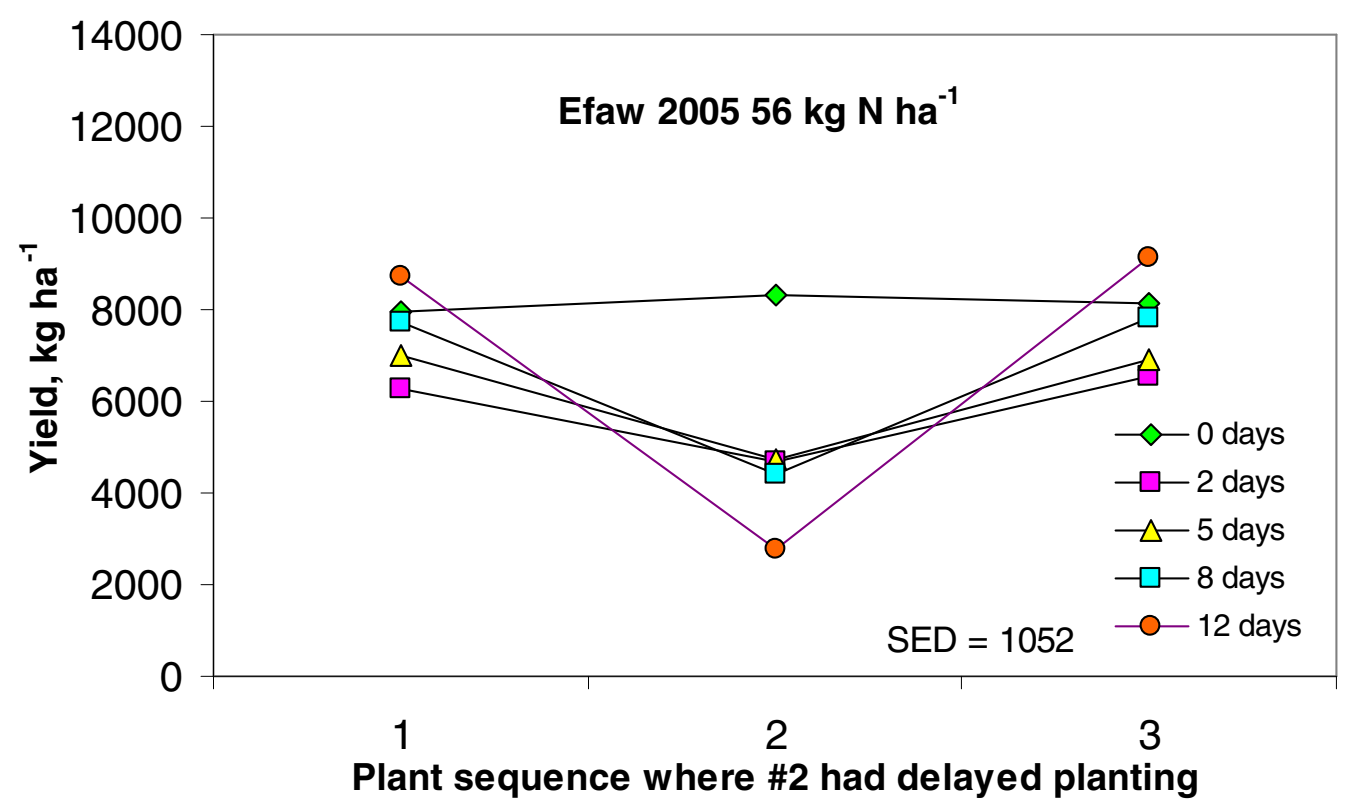

Figure 3. Three plant sequence where \#2 was planted $0,2,5$, 8, and 12 days later, $56 \mathrm{~kg} \mathrm{~N} \mathrm{ha}^{-1}$ applied preplant, Efaw 2005 (each point represents the average of nine plants repeated in these 3-plant sequences).

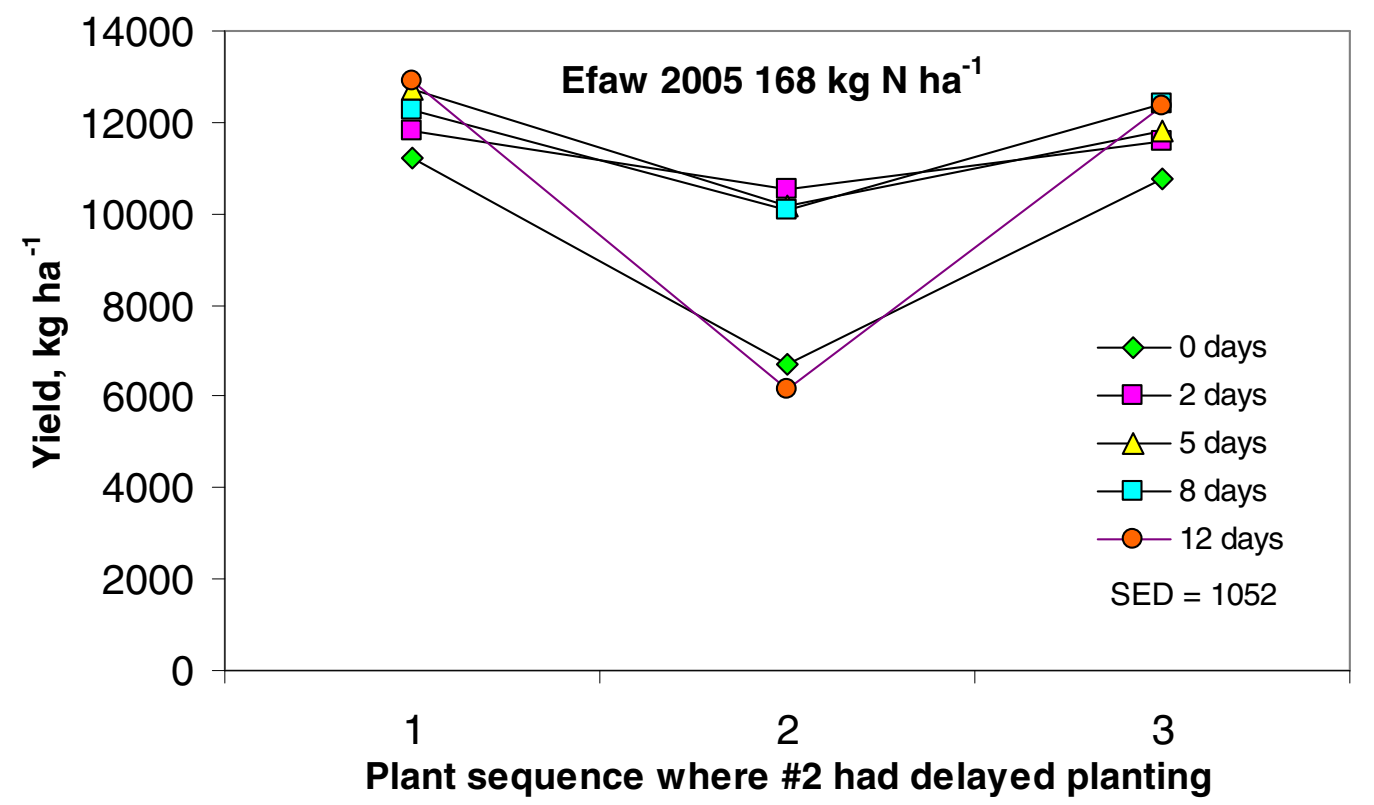

Figure 4. Three plant sequence where \#2 was planted $0,2,5,8$, and 12 days later, $168 \mathrm{~kg} \mathrm{~N} \mathrm{ha}^{-1}$ applied preplant, Efaw 2005 (each point represents the average of nine plants repeated in these 3-plant sequences). 


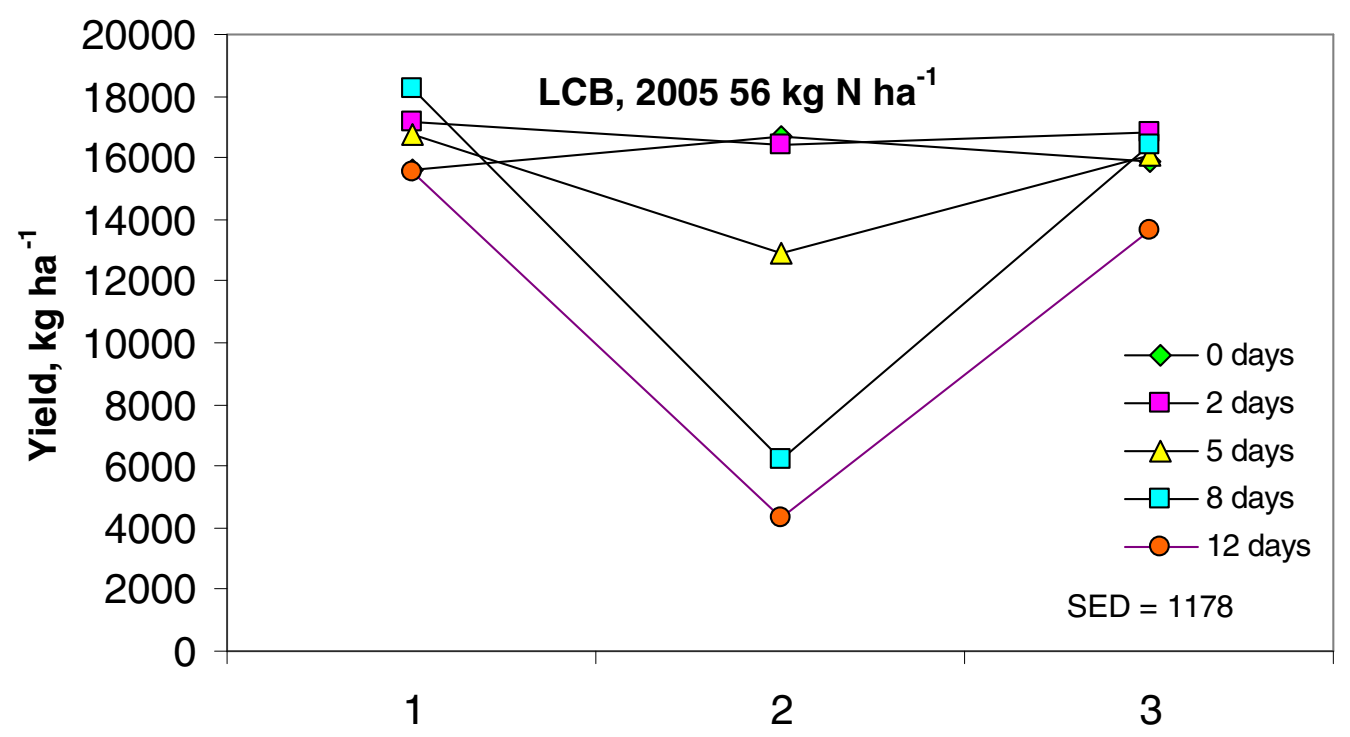

Plant sequence where \#2 had delayed planting

Figure 5. Three plant sequence where \#2 was planted $0,2,5,8$, and 12 days later, $56 \mathrm{~kg} \mathrm{~N}^{-1}$ applied preplant, Lake Carl Blackwell 2005 (each point represents the average of nine plants repeated in these 3-plant sequences).

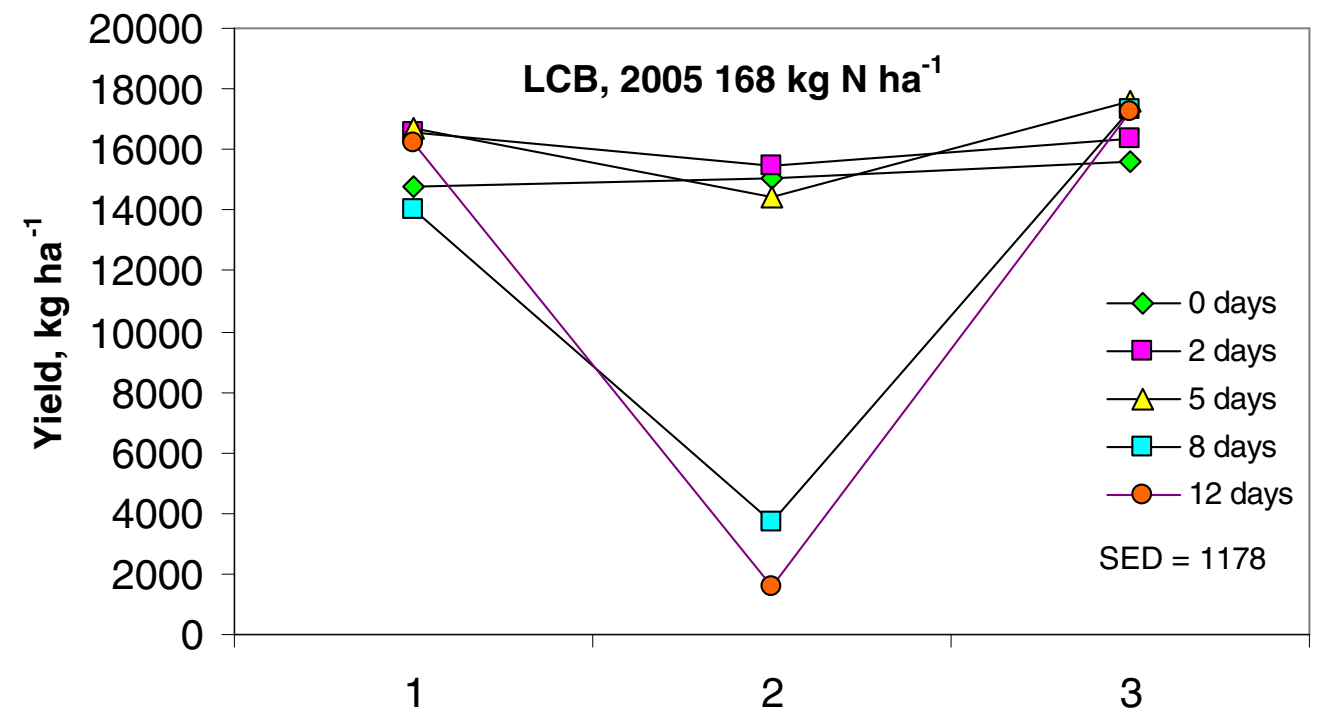

Plant sequence where \#2 had delayed planting

Figure 6. Three plant sequence where \#2 was planted $0,2,5,8$, and 12 days later, $168 \mathrm{~kg} \mathrm{~N} \mathrm{ha}^{-1}$ applied preplant, Lake Carl Blackwell 2005 (each point represents the average of nine plants repeated in these 3-plant sequences). 


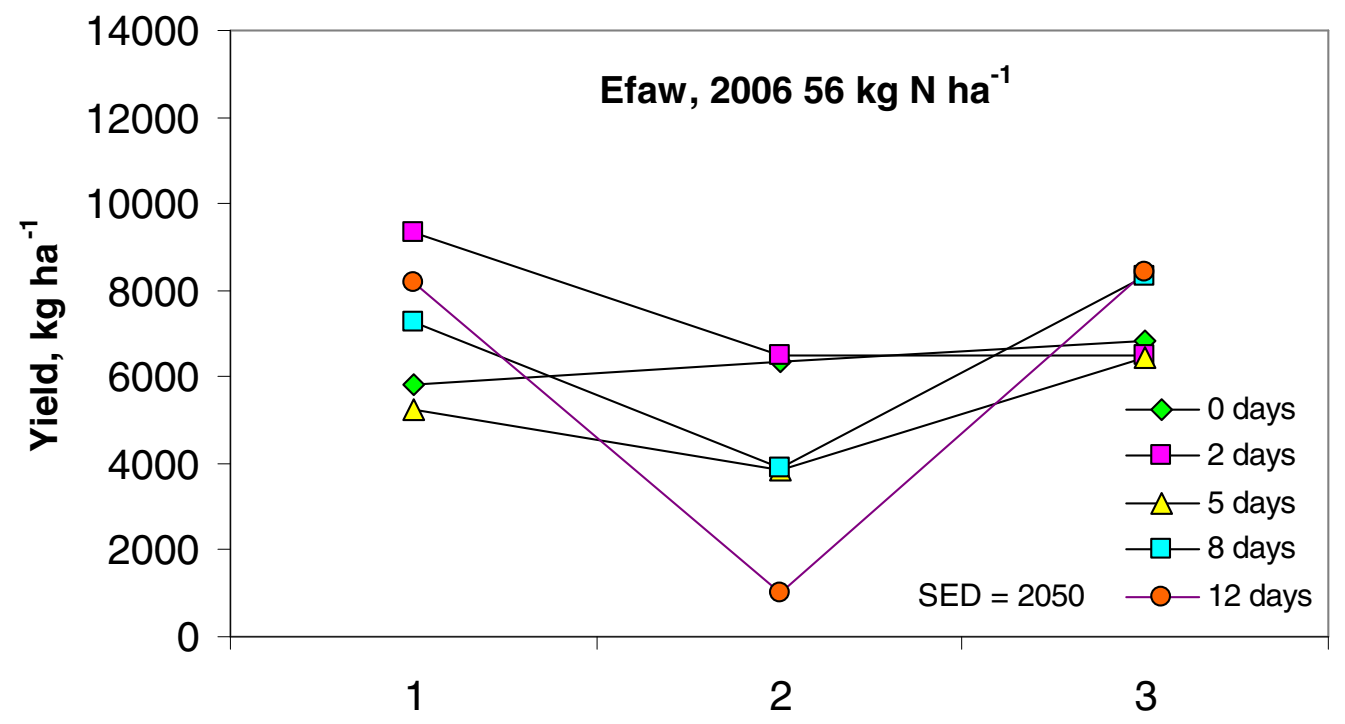

Plant sequence where \#2 had delayed planting

Figure 7. Three plant sequence where \#2 was planted $0,2,5,8$, and 12 days later, $56 \mathrm{~kg} \mathrm{~N} \mathrm{ha}^{-1}$ applied preplant, Efaw 2006 (each point represents the average of nine plants repeated in these 3-plant sequences).

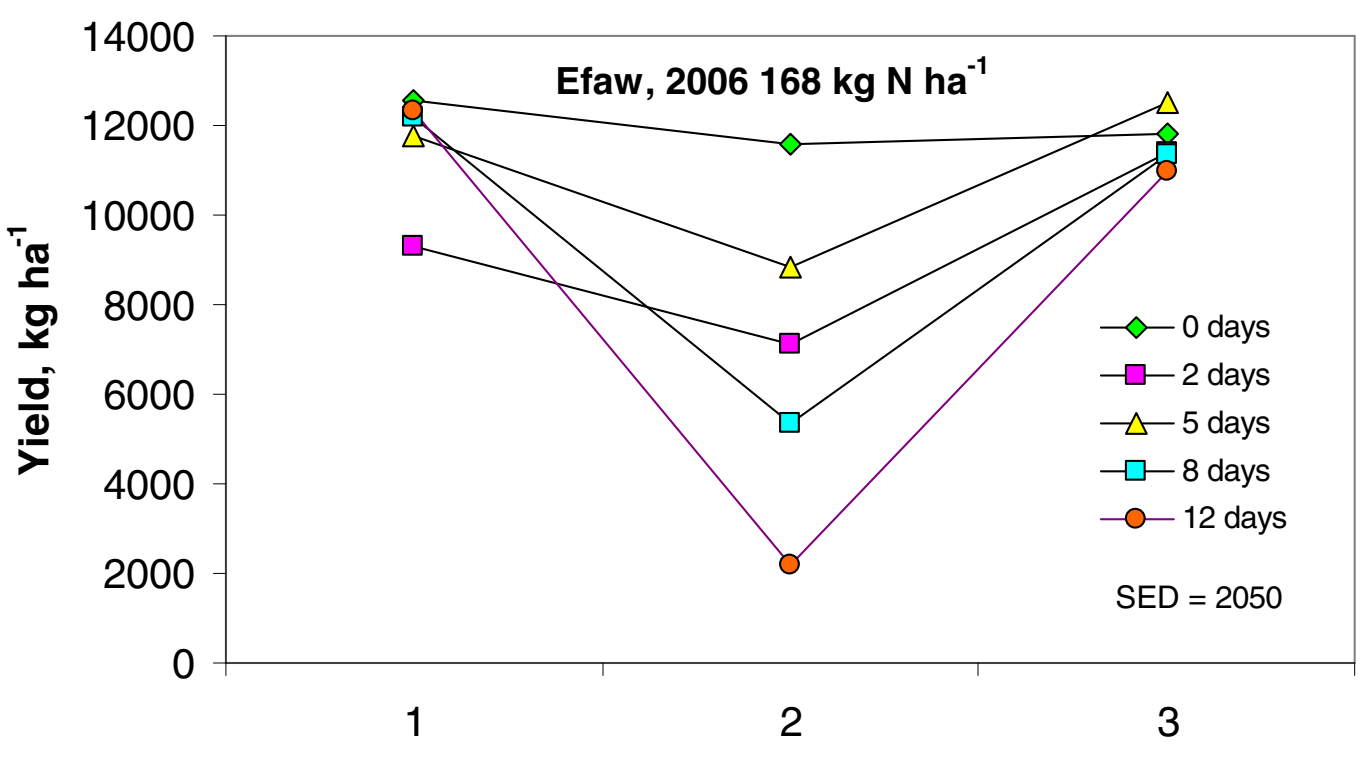

Plant sequence where \#2 had delayed planting

Figure 8. Three plant sequence where \#2 was planted $0,2,5,8$, and 12 days later, $168 \mathrm{~kg} \mathrm{~N} \mathrm{ha}^{-1}$ applied preplant, Efaw 2006 (each point represents the average of nine plants repeated in these 3-plant sequences). 


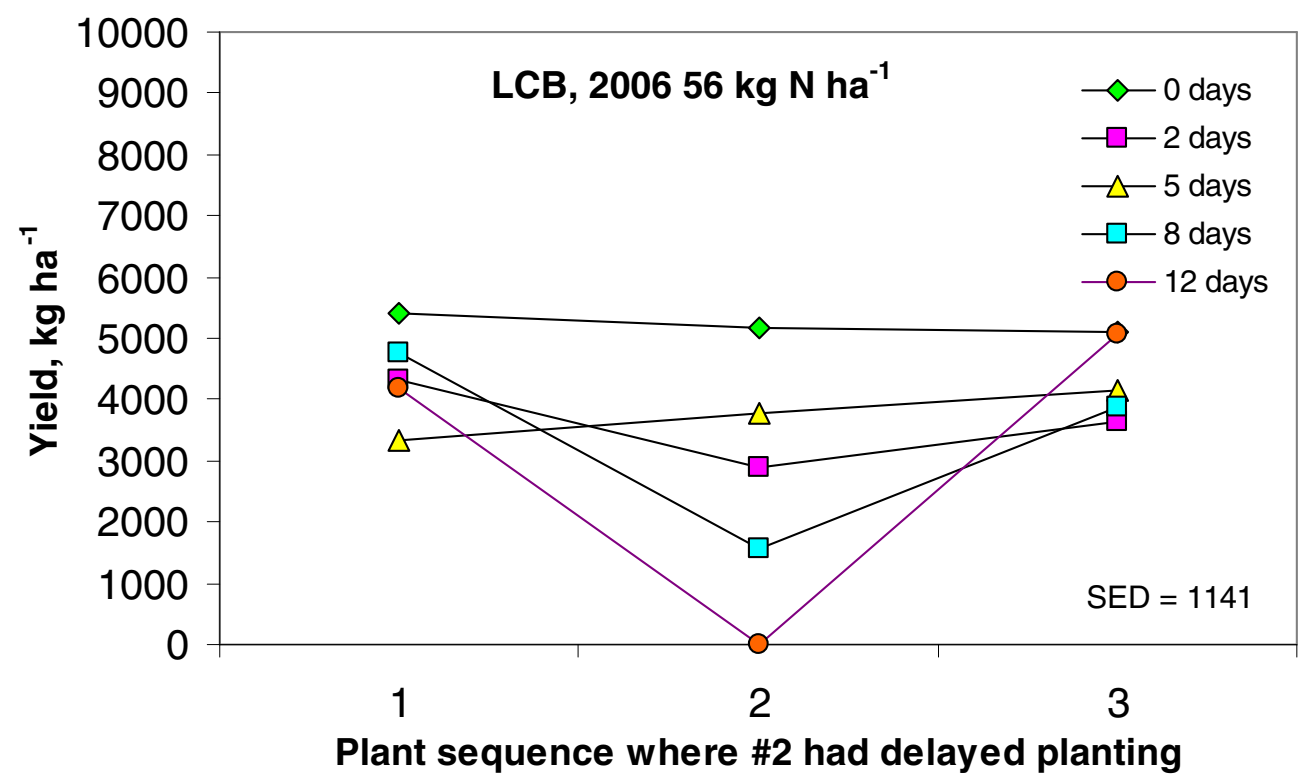

Figure 9. Three plant sequence where \#2 was planted $0,2,5,8$, and 12 days later, $56 \mathrm{~kg} \mathrm{~N} \mathrm{ha}^{-1}$ applied preplant, Lake Carl Blackwell 2006 (each point represents the average of nine plants repeated in these 3-plant sequences).

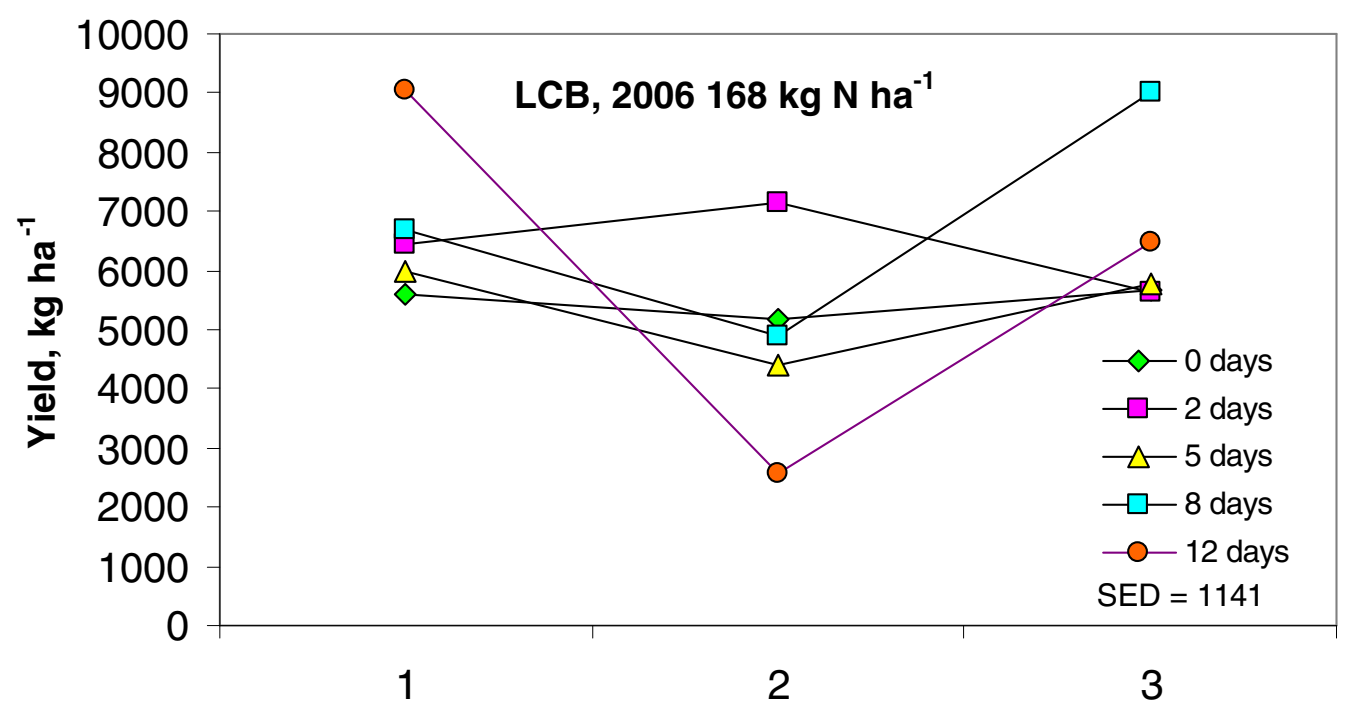

Plant sequence where \#2 had delayed planting

Figure 10. Three plant sequence where \#2 was planted $0,2,5,8$, and 12 days later, $168 \mathrm{~kg} \mathrm{~N} \mathrm{ha}^{-1}$ applied preplant, Lake Carl Blackwell 2006 (each point represents the average of nine plants repeated in these 3-plant sequences). 


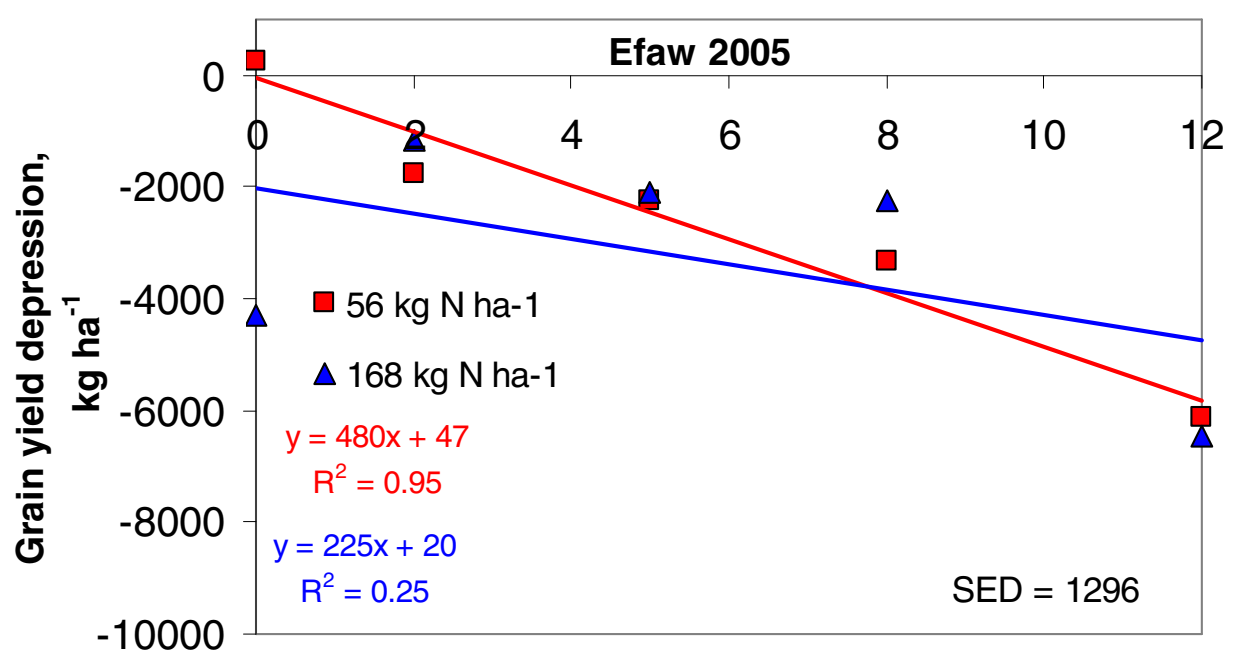

Planting delay, days

Figure 11. Corn grain yield depression in $\mathrm{kg} \mathrm{ha}^{-1}$ when the center plant was delayed 0, 2, 5, 8, and 12 days, Efaw 2005.

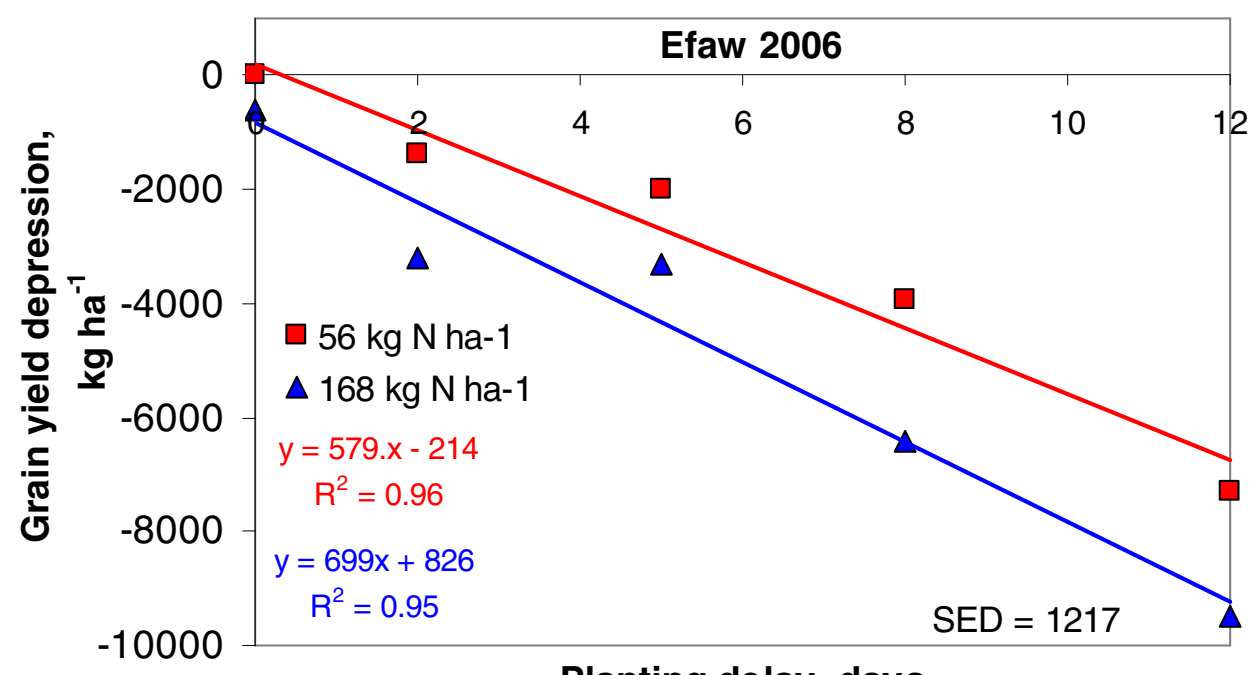

Planting delay, days

Figure 12. Corn grain yield depression in $\mathrm{kg} \mathrm{ha}^{-1}$ when the center plant was delayed $0,2,5,8$, and 12 days, Efaw 2006. 


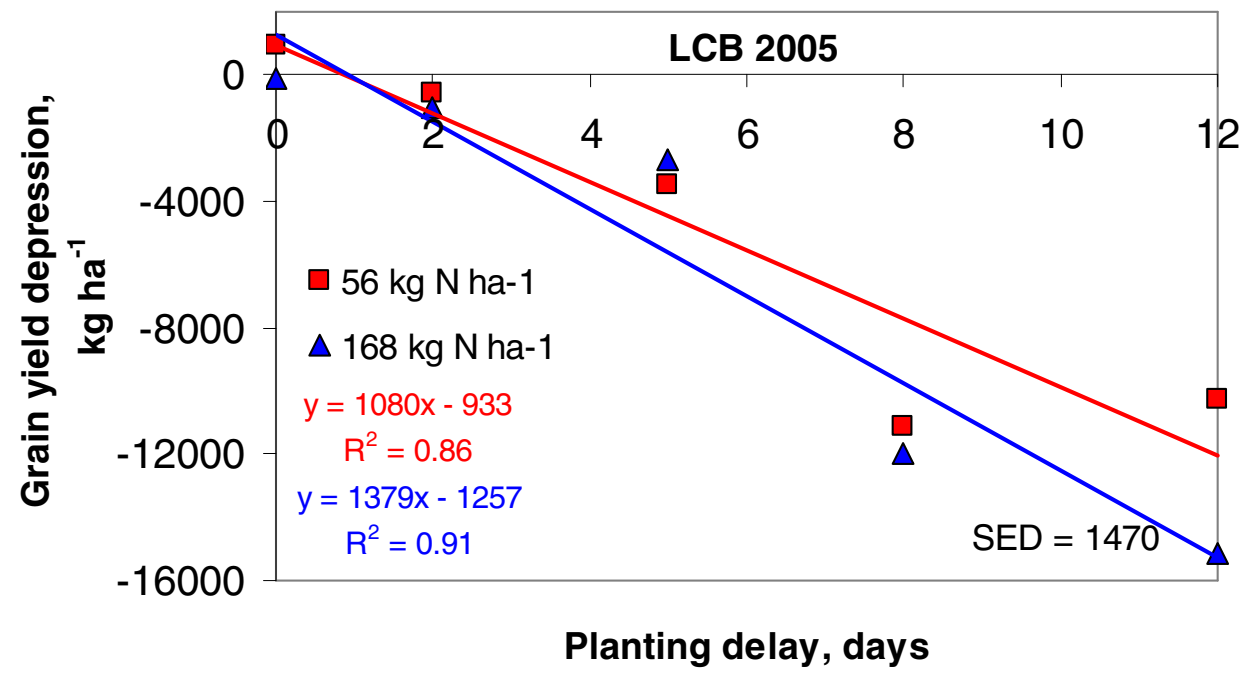

Figure 13. Corn grain yield depression in $\mathrm{kg} \mathrm{ha}^{-1}$ when the center plant was delayed 0, 2, 5, 8, and 12 days, LCB 2005.

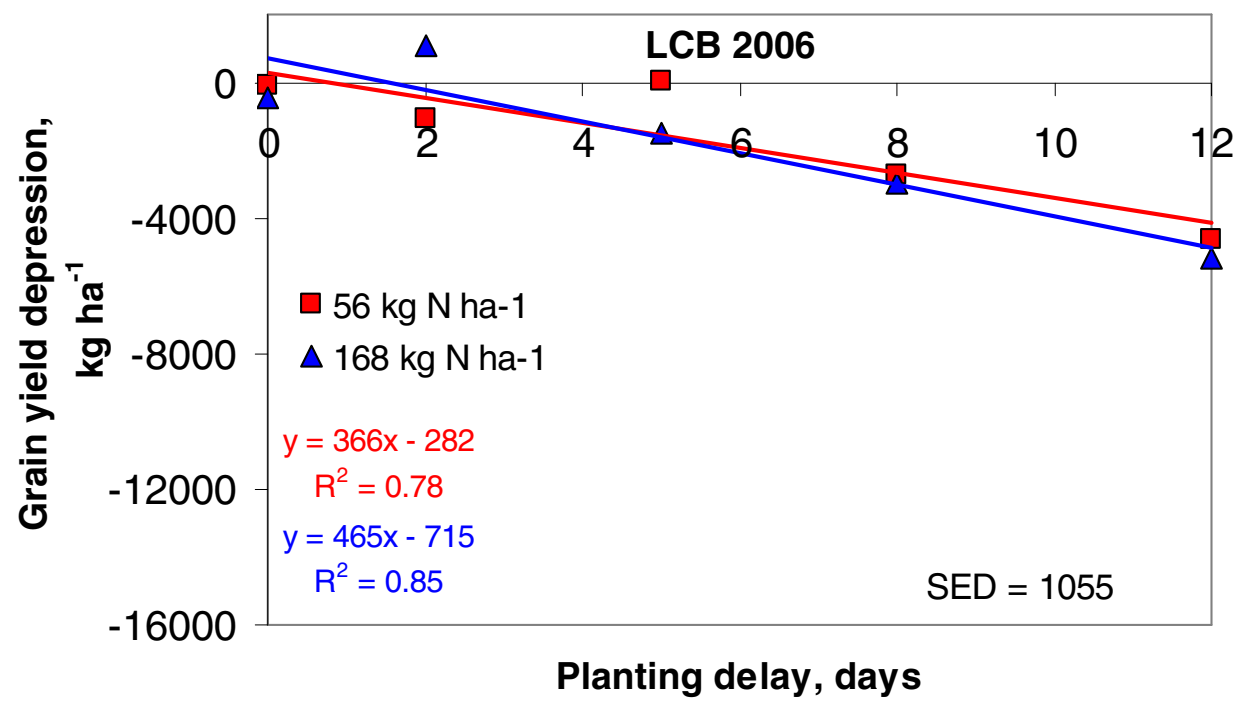

Figure 14. Corn grain yield depression in $\mathrm{kg} \mathrm{ha}^{-1}$ when the center plant was delayed 0, 2, 5, 8, and 12 days, LCB 2006. 


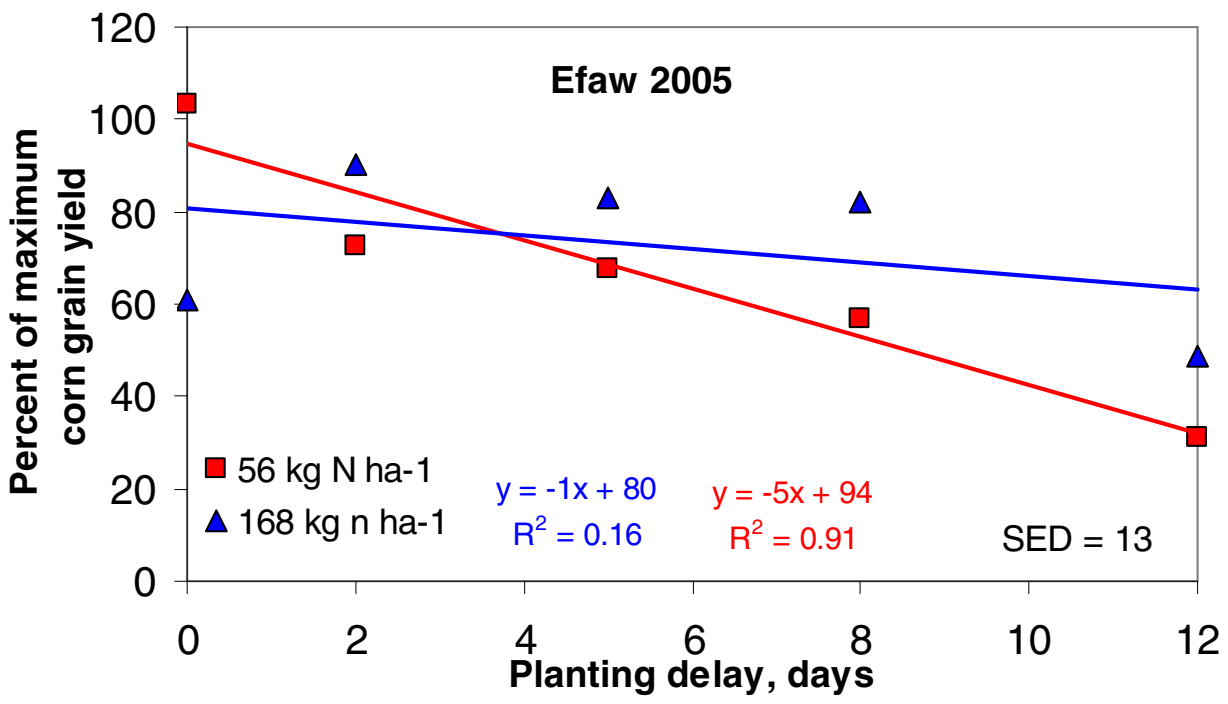

Figure 15. Three plant average when the center plant was delayed $0,2,5,8$, and 12 days expressed as percent of maximum corn grain yields, Efaw 2005.

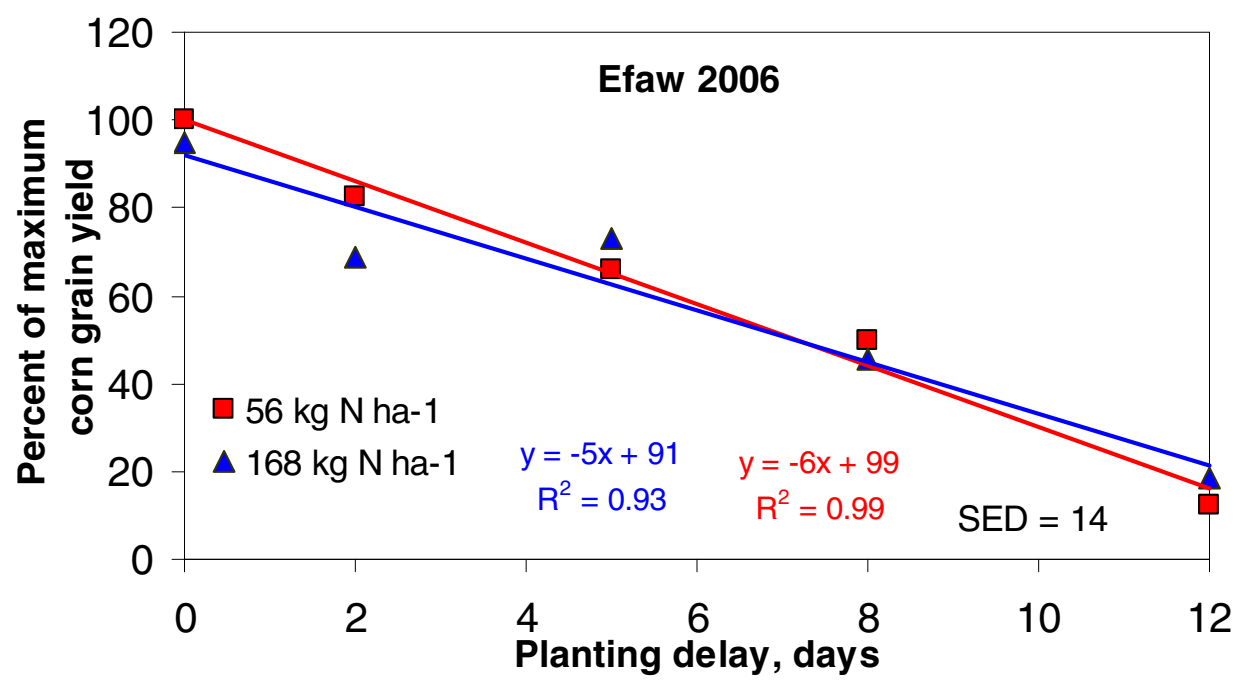

Figure 16. Three plant average when the center plant was delayed $0,2,5,8$, and 12 days expressed as percent of maximum corn grain yields, Efaw 2006. 


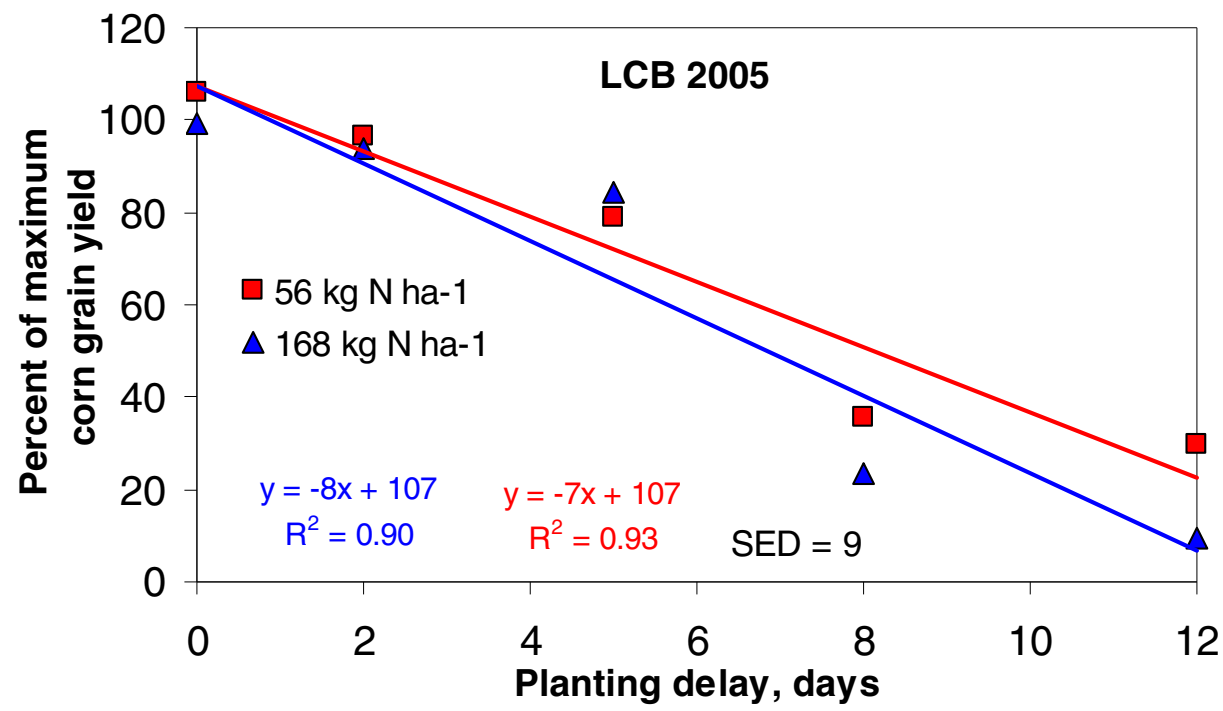

Figure 17. Three plant average when the center plant was delayed $0,2,5,8$, and 12 days expressed as percent of maximum corn grain yields, LCB 2005.

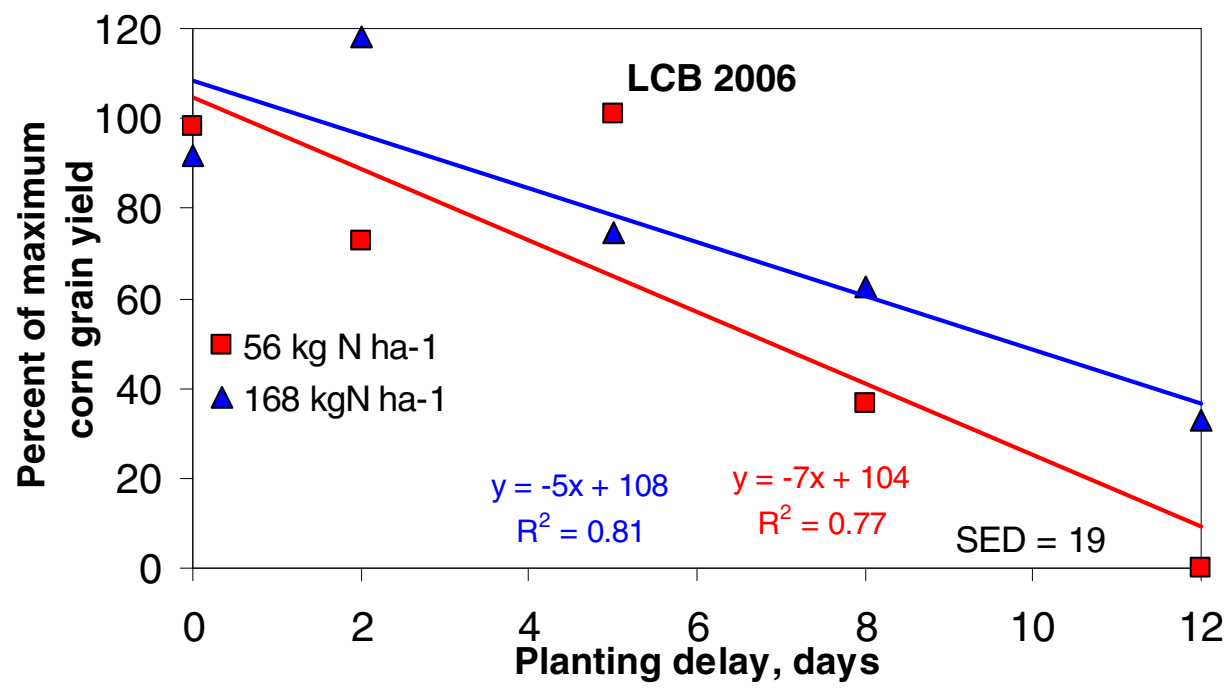

Figure 18. Three plant average when the center plant was delayed $0,2,5,8$, and 12 days expressed as percent of maximum corn grain yields, LCB 2006. 
VITA

Kyle Don Lawles

Candidate for the Degree of

Masters of Science

Thesis: EFFECT OF DELAYED EMERGENCE ON CORN GRAIN YIELDS

Major Field: Plant and Soil Sciences

Bibliography:

Education: Graduated from Hydro High School, Hydro, Oklahoma in May 2000; received Bachelor of Science degree in Plant and Soil Sciences from Oklahoma State University Stillwater, Oklahoma 2005. Completed the requirements for Masters of Science degree with a major in Plant and Soil Science at Oklahoma State University in December, 2006.

Experience: Raised on a farm near Hydro, Oklahoma; employed as a farm hand and mechanic during the summer; employed by Oklahoma State University, Department of Plant and Soil Sciences, as an undergraduate student assistant and graduate research assistant; Oklahoma State University, Department of Plant and Soil Sciences, 2002- present.

Professional Memberships: ASA 
Name: Kyle Don Lawles

Institution: Oklahoma State University
Date of Degree: December, 2006

Location: Stillwater, Oklahoma

Title of Study: EFFECT OF DELAYED EMERGENCE ON CORN GRAIN YIELDS

Pages in Study: $30 \quad$ Candidates for the Degree of Masters of Science

Major Field: Plant and Soil Science

Scope and Method of Study:

The purpose of this study was to determine corn grain yield reduction as a function of interplant competition arising from delayed emergence and to evaluate yield levels associated with 3 plant sequences, with and without delayed emergence.

Findings and Conclusions:

Delayed planting to simulate delayed emergence was used in this experiment to determine the adverse effects on final corn grain yield. When comparing 3 plant sequences, the results show that delayed emerging plants result in decreased corn grain yields. Over both sites and years, data showed that when the days of delayed planting was greater than 5 days there was almost always a significant yield reduction. When looking at the three plant sequences the delayed plant by 2,5 , and 8 days continued to compete with the two non delayed plants. By 12 days these plants competed less with the two non delayed plants and that then tended to have higher byplant yields. Results from this study will assist those groups interested in improving byplant $\mathrm{N}$ fertilization by knowing how much a plant is delayed and how that ultimately affects final corn grain yields. This information will in turn be used to estimate $\mathrm{N}$ removal based on yield level (or projected yield decrease) based on how much each plant is or is not delayed versus neighboring plants. When evaluating both sites and years, for each day delay emergence (estimated using delayed planting), grain yield depression ranged from $225 \mathrm{~kg} \mathrm{ha}^{-1}$ to $1379 \mathrm{~kg} \mathrm{ha}^{-1}$. 